\title{
Foreign Military Assistance and Political Attitudes in Developing African Countries
}

\section{by William Gutteridge}

The American military assistance programme in Latin America was explicitly conceived in ideological terms as part of a general diplomatic strategy. It is only necessary to read General Robert J. Wood's foreword to Harold Hovey's book ${ }^{1}$ United States Military Assistance: a Study of Policies and Practices to appreciate the point: "It is a program which provides military equipment and weapons and training to those allied and friendly nations which share our view as to the threat of international communism" ( $p$. vi). More recently, Ernest Lefever in his book ${ }^{2}$ Spear and Scepter: Army, Police and Politics in Tropical Africa has set as one of his objectives a consideration of the appropriate nature of U.S. policy on military and public safety aid for African countries in terms of stability and security in the area concerned, as defined, of course, by Washington. It is tempting to suggest that British and French attitudes to this question are less calculating and even largely unplanned. It may be more correct to describe them as wary because of their greater experience of the refreshing unpredictability of African political response. They may also have discovered the futility of political engineering of this kind and learnt to be grateful for accidental benefits accruing from the residual imperial ties. Nevertheless, it is reasonable to assume that their actions in providing military assistance are generally seen as furthering their own national interest.

There is unquestionably a widespread view that the African and other non-European graduates of Sandhurst and St. Cyr are imbued with a set of political values congruent with the phi-

* Director of Complementary Studies, the University of Aston in Birmingham.

1

New York, 1965.

2 The Brookings Institution, Washington D.C., 1970. 
losophy and objectives of those by whom they have been trained. The object of this short article is to examine the extent to which this may be true, especially in so far as those trained in or by Britain are concerned, and the practical consequences stemming from it. The superficial evidence is contradictory outside Africa senior officers trained in the British mode and even brought up in the same force have behaved apparently differently in India and Pakistan. Similarly, inside Africa, in Ghana (1966) and Uganda (1971) presidents not avowedly prowestern were overthrown in circumstances not unsatisfactory from an official British standpoint; but in Nigeria (also in 1966) Sir Abubakar Tafawa Balewa, the Prime Minister, was murdered in an abortive military coup at a time when he was still the favoured African leader in European eyes. Bob Fitch and Mary Oppenheimer castigated the officers who carried out the original Ghana coup as Anglo-Africans in Marxist terms similar to those employed by Jean-Paul Sartre denouncing racial treachery in his preface to Fanon's The Wretched of the Earth. They also suggested that the CIA and the British Intelligence Service using these men as pawns might well have had a hand in the overthrow of Kwame Nkrumah. A recent article in The Daily TeZegroph (Colour Supplement, January 21st, 1972) by E.H. Cookridge categorically asserts the role played by the CIA in this coup and in the setting up as head of state of Yakubu Gowon in Nigeria, and suggested similar activity in conjunction with the British in the deposing of President Obote of Uganda. It seems unlikely, however, that the ending of $\mathrm{Dr}$. Busia's government in Ghana by Colonel I.K. Acheampong was either engineered by Western agents or greeted with enthusiasm in Whitehall even though the political stance he has so far adopted is moderate rather than radical. On this evidence alone, it would clearly be naive to suppose - and there are plenty more examples from Nasser onwards to support this that those trained by a foreign power necessarily become its tools. An attempt to relate the content and style of military education to the subsequent political actions and pronouncements of individuals is, therefore, required.

Generally speaking, Western European military academies like Sandhurst and St. Cyr are more concerned with the building up of a professional ethos than with political education. At Sandhurst, in particular, where British and overseas cadets have undergone exactly the same course, the confidence derived from a long tradition means that many aspects of professional

1 Fitch and Oppenheimer, Ghana: the End of an IZZusion. 
training are implicit in the example set rather than explicit and consciously disseminated. An ideal of the military prevails. It goes without saying that the army should be structurally and ideologically cohesive with a high level of internal discipline. It is assumed that officers are publicly regarded and regard themselves as a main repository of patriotism, dedicated to the public interest and perhaps imbued with quasi-puritanical virtues. What is to be questioned is not the prevalence of this ethos within a closed institution, but its effect on those from wholly or partly - and Africans have often had a British style of schooling - alien cultural environments. Though an interest in the Commonwealth relationship was admittedly cultivated during the $1950^{\prime} \mathrm{s}$, it is doubtful if it can be validly said that, in any deliberate sense, the political or antipolitical attitudes of the Western military were impressed upon the African cadet. Nor was or is he wholly isolated during his stay in Europe from his African contemporaries. In Britain, he normally has continual opportunity to restore his own cultural identification through his military contemporaries and student and other ethnic associations in London.

This is not to say, however, that African officers have not suffered any strain from divided loyalties. If they were commissioned before independence, they had the disconcerting experience of serving a foreign power in the company of expatriates, and even after independence the absorption of the military institutions fully into the pattern of the new state was probably a slower process than, for example, with the civil service. This was partly a function of that characteristic feature of the Western military - its separateness in physical terms in barracks or cantonments from the society which it is supposed to serve. To be in a racial minority in the officer corps of one's own country and at the same time to be exposed to the pull of ethnic allegiance during a period when the political leadership was only slowly coming to appreciate the armed forces as a national institution was a toughening, not to say confusing, experience. It would not be surprising, therefore, if an individual were to rely heavily on the behavioural guidance to be derived from certain basic professional tenets. An interesting question is the extent to which the writings of officers involved in political action reveal the true nature of the influences to which they were seemingly responding.

Two of the Ghanaian military elite have written books, the tone of which has agreeably surprised or shocked readers according to their ideological standpoints. Within months of 
the overthrow of Nkrumah the then Colonel A.A. Afrifa wrote and published The Ghana Coup. His received impression of Sandhurst as a kind of military 'nirvana' where all the simple virtues are practised is obviously not easy to accept at its face value: "Now I look back on Sandhurst with nostalgia... It is an institution that teaches that all men are equal, that the profession of men-at-arms is essential, and a peaceful one. It shows the stupidity of racial conflicts, and the joy of the communion of all men in the service of peace" or "Sandhurst gave us independent thinking, tolerance and a liberal outlook... There was no discrimination whatsoever". It is significant that it is not the Royal Military Academy alone which is the subject of this kind of romantic description. Afrifa writes also of the British "traditions of integrity, fair play and above all honour", and refers to Britain as the home of democracy, while in the same passage he cites the case of Oliver Cromwell before he eventually distinguishes between "allegiance and loyalty to the Government of Ghana" and "allegiance to the people of Ghana". All this amounts not only to a seemingly exaggerated admiration for the British way of life but also, and more significantly, to the acceptance of the British military as the norm to be used in determining his own behaviour. The fact that by no means all overseas cadets have left Britain with this kind of impression and that many of Afrifa's British contemporaries might have some difficulty in recognizing the institution which he describes suggests not so much any deliberate indoctrination but a more accidental result of a convergence of particular experiences in some individuals. It is clearly a matter of opinion whether the consequences have been good or bad, but in either case they are more reasonably attributable to the inevitable cultural permeation accompanying colonial rule than to any deliberately conceived policy. Total resistance to the temptation to exploit the situation was, of course, not to be expected, but there is as yet no convincing evidence to suggest that General Kotoka and Colonel Afrifa in launching the original Ghan coup did other than act in accordance with their own lights by reference to their own experience. That chey might have acted differently if they had been trained under other auspices is clearly possible, but for an understanding of the phenomenon largely irrelevant. Only an officer corps trained in accordance with an explicitly Ghanaian military tradition would have been free from the influence of external cultural norms and this was impracticable at the time. 
On matters of domestic politics Major General Albert Ocran in his book $A$ Myth is Broken reflects an even more simplistic view than does Afrifa. In a passage of some length he recounts in detail the changes for the worse in military conditions of service during the Nkrumah period. Reduced travelling allowances, increased rents, cancellation of free passages abroad for the children of service personnel, and increased charges for electricity all lead to the conclusion "When the British were here our interests were better protected". Such measures are seen as wholly discriminatory and never for a moment examined in a wider context as an aspect of a necessary austerity policy. It is ironic that this situation was and remains a direct result of nationalist pressures during decolonization for scales and allowances for local public servants equivalent to those for expatriates - a development which for obvious reasons was generally resisted at first by the colonial power. What is much more difficult to assess, however, is the real extent of the identity of men like Ocran and Afrifa with a main strand of Ghanaian or African nationalism. Are they other than military representatives of the middle class 'intelligentsia' or 'elite' which fairly consistently opposed Nkrumah and the CPP? Clearly, their proclaimed patriotism is not such as to have generated in them any degree of xenophobia for the white men from whom they received their training, a feature which some would regard as characteristic of the typical patriotism of military professionals. What is probable, however, is an enhancement or magnification of the antipolitical attitudes implicitly fostered in a military academy as a result of their expatriate colleagues' tacit attitudes to the leaders of the independence movement. But again, the Ghana officer corps included men similarly trained but of a wide range of political attitudes and some were committed anti-colonialists, at any rate beneath the surface.

The attitudes of Generals Afrifa and Ocran towards external policy may, however, be useful in providing a further dimension to this discussion. In neither of the cases quoted is a critical view of the Commonwealth relationship to be found. Thus, Afrifa writes: "One of the reasons for my bitterness against Kwame Nkrumah's rule was that he paid only lip-service to our membership of the Commonweal th of Nations"; Nkrumah, he goes on to say, made the Commonwealth a mockery "under the mask of African unity and non-alignment". Ocran refers to Ghanaian soldiers as dying in the past "to defend the Commonwealth, their country and Africa's freedom" in that order, and this corresponds with another of Afrifa's sentences "I have been trained in the United Kingdom as a soldier, and $I$ am ever prepared to fight alongside my friends in the United Kingdom 
in the same way as Canadians and Australians will do". The professed faith in Magna Carta and British institutions generally extends to more topical matters - "I (Afrifa) personally knew that Her Majesty's Government of the United Kingdom was quite capable of dealing with the Rhodesian situation". Strong opposition to cadets training in Russia may, however, be primarily attributed to a legitimate fear of the development of factions in an army with different military traditions tending to emphasize stratification by rank and age-group, but Ocran does raise the ideological issue: "The saying that 'East is East and West is West and never the twain shall meet' came to acquire a new and more vivid meaning for me when Nkrumah took his leftward turn and tried to drag the country and the army with him". Throughout both books a concern, albeit confused, for the reputation of Ghana in the world is apparent. It is characteristic and understandable that the norm by which this national reputation should be judged is, as with the standard of living and life style of the military officer, that of the one external reference point known at first hand to the writers. It should, therefore, have been no surprise to find that the National Liberation Council organized by the coup leaders including Afrifa and Ocran pursued economic and foreign policies consonant with a continuing reference to a Western model. The possible repudiation of the debts incurred by Nkrumah never seems to have been a factor in their conduct of affairs in spite of the obvious handicaps deriving from them; but it has, interestingly, already become a feature of Colonel Acheampong's administration. The ideological sympathies of these particular men involved in the overthrow of Nkrumah are not, therefore, seriously in doubt.

Two aspects are, however, questionable. In the first place, it may be true that any form of foreign military training is, because of the unique relationship between the military and the state, likely to have a comprehensive impact on the trainee. On the other hand, the effects deduced in the two cases available for analysis seem, from first hand observation, far from universal. The documentation of a different Ghanaian example would not, however, be easy, though in due course it may be possible to discover more of the attitudes of Major-General Charles Barwah, killed in the 1966 coup. He seems to have understood the apolitical virtue learnt from the British to imply strictly an unquestioning and, in the event, fatal support of Nkrumah. In Nigeria, there was more overt xenophobia expressed in the officers' 
mess before expatriates finally left.

The special significance of Major Nzeogwu's case in this context is that he was a strict contemporary of Afrifa's at Sandhurst, training in the same company and receiving an identical education. And yet his specifically Nigerian nationalism was not in 1966 ever in dispute. All the evidence goes to suggest that Dr. Azikiwe was right to describe him and his associates as 'Young Turks' with the full radical and modernizing implications of the term. In no sense could the January 1966 plot including the assassination of the Sardauna of Sokoto be attributed to a western ideology acquired in the course of military training. Indeed Nzeogwu, on his return to Nigeria as a commissioned officer, rapidly acquired the reputation amongst British of ficers of being 'bloody-minded' and ruthless in assertion of Afro-Nigerian interest. He was in their view the exact opposite of a somewhat earlier graduate of Sandhurst - namely Gowon, who, in his turn, suffered in the eyes of fellow Nigerians for being too westernized, an understandable assumption by those who might have seen him in Britain, in dark suit with rolled umbrella, the formal offduty uniform of the British officer of the time.

In his recent book ${ }^{1}$ The Nigerian Military, Robin Luckham has provided much fresh evidence of the Nigerian officer corps' social and political attitudes. In a pastiche of scarce published material and his own wide personal impressions he suggests a pervasive ambivalence on the part of the officers concerned in the January 1966 coups. They were on the one hand ultra-nationalists with revolutionary objectives, while at the same time concerned with collective military honour and their status within a social elite, the values of which were derived from Western models. The contradiction, apparent in some of them and in many of their colleagues, between 'the country gentleman posture of British officers' and strongly Pan-African or anti-white racial attitudes seemed to go unremarked even when heightened by the tensions over the deployment of mercenaries during the civil war. The conflict between conformism and revolt remains, Dr. Luckham reasonably claims, unresolved. The professional ethos as adapted, and perhaps distorted, to fit a different cultural style seems more influential than its source.

This problem of the ideological-cultural impact of foreign military assistance lacks as yet the necessary documentation

Cambridge University Press, 1972. 
for a full comparative study. It is easy to appreciate that a diversification of military assistance produces as many, though different, problems as a homogeneous arrangement. It would be interesting to be able to compare the political effects of communist and Israeli training in different sectors of the Uganda air force with MIG and Mirage aircraft respectively. Colonel Charles Beausoleil of the Ghana Air Force, who has come to the force in Colonel Acheampong's administration was both educated at Sandhurst and trained to fly by Israeli instructors. The ramifications of the training pattern are almost unlimited. What might be supposed to be the consequences of Pakistan military training either at cadet or staff level?

Kwame Nkrumah thought it politically potentially dangerous after the 1958 Pakistani coup and severed the connection.

In some French speaking countries, soldiers like Colonel A.A. Alley in Dahomey, who were trained in French military schools from an early age have taken decisive political action of a conservative kind, while others less thoroughly inbued with the tradition - for example, in Mali - have adopted a more radical stance.

The difficulty may well lie in assuming a specific political consequence of any form of military aid. The Ghanaian case illustrates well the frustrations inherent in a conventional ideological attribution of behaviour. On present evidence a more logical conclusion at which to arrive may well be that in many cases the military actually have no socio-political interest in the ideological sense: their primary concern is for their professional interest and the defence of it against threats apparently posed by ambitious or misguided politicians. It might not even be absurd to postulate the possibility that the coup, in the first instance, is sometimes seen as a step towards the reassertion of the principle of the non-political army. The domestic stagnation - in sociopolitical terms - which has been characteristic of a period of military rule in many countries suggests a lack of ideological orientation, while governmental tactics have continually betrayed a deficiency in political perception. For example, the National Liberation Council in Ghana from 196669 so far from severing all connections with the Nkrumah regime often failed to perceive that it was associating with tainted elements, and imposing a moratorium on all political activity may actually have prevented the emergence of a dynamically different grouping. The current malaise now apparent in General Gowon's government in Nigeria, though the circumstances are different, seems in some ways parallel. The 
general unwillingness, and perhaps inability, to interfere with the civil service, the police and the other public services suggests that there is no strong political motivation. The overweening role of the military in many African countries may be attributed more to the lack of political integration in the country at large than to any foreign political influence on the military. In all the circumstances, it seems that the peculiar character of the elitist military traditions wherever they are inherited from constitutes a danger to the political development of politically underdeveloped states. It may be going too far to suggest that by a quirk of fate a military tradition has proved not the most difficult but the easiest of traditions to establish, and that this has led to disequilibrium and asymetry in the development of new nations. For this reason, the search, as in Tanzania, for a new, possibly nonelitist, formula for a military institution may prove of particular significance. 